\title{
Corporate Governance in Banks and its Impact on Credit and Liquidity Risks: Case of Tunisian Banks
}

\author{
Nesrine DJEBALI (Corresponding author) \\ University of Jendouba, Faculty of Law \\ Economics and Management of Jendouba, Tunisia
}

Tel: 216-22-961-769E-mail: djbeli.nesrine@gmail.com

Khemais ZAGHDOUDI

University of Jendouba, Faculty of Law

Economics and Management of Jendouba, Tunisia

Tel: 216-98-553-863Ｅ-mail: k.zaghdoudi@yahoo.fr

\begin{abstract}
Received: Nov.18, $2018 \quad$ Accepted: Dec. 2, $2019 \quad$ Published: December 2, 2019
doi:10.5296/ajfa.v11i2.13929 URL: https://doi.org/10.5296/ajfa.v11i2.13929
\end{abstract}

\begin{abstract}
Given the crucial role played by banks in a developing country like Tunisia, it is important to maintain their stability. The purpose of this article is twofold. First, it studies the effect of banking governance on credit risk. Second, it tests the relationship between bank governance mechanisms and liquidity risk. In this article, we have combined literature regarding two areas of governance, first, ownership structure and board characteristics, and second, their impact on banking risks. To achieve this goal, we used a sample of 10 Tunisian banks observed during the period 1998-2015. The econometric approach used in this study is based on both the fixed and random effects models of panel data analysis. Our results show that credit risk and liquidity risk are directly related to bank governance mechanisms. These findings enable bank managers to better understand the factors influencing bank risk and serve as a basis for regulations to strengthen bank governance.
\end{abstract}

Keywords: Board of Directors, Institutional Ownership, Credit Risk, Liquidity Risk, Stability, Tunisian Banks. 


\section{Introduction}

Liquidity and credit risks are positively related and jointly contribute to bank volatility. In a recent study, based on a sample of 49 banks in the MENA region from 2006 to 2013, Ghenimi A. et al. (2017) examined the main sources of bank fragility. Their analysis is based on the relationship between credit risk and liquidity risk and their impact on bank stability. In a note from the Basel Committee on Banking Supervision (2016), good corporate governance for banking organizations increases the effectiveness of risk management, thereby increasing the financial strength of these entities. In order to assess the progress made by the banking sector in the area of risk governance, the Financial Stability Board (FSB) published a thematic analysis on governance in February 2013. Such analysis encourages financial institutions and national authorities to take steps to improve risk governance. In general, banks deliberately take the financial risk to generate revenue and serve their customers, resulting in asymmetric information. However, good internal governance of banks is essential, forcing boards to focus more on risk assessment, management and mitigation. Hence our problem is presented as follows: What is the impact of the governance mechanisms of characteristics of the board of directors and ownership structure on the risks of Tunisian banks, which continue to occupy a leading position in the financing of the economy?

We have chosen a developing country such as Tunisia for several reasons. First, given the crucial role played by banks in Tunisia's economy, it is important to maintain their stability. The stability of the banking system essentially leads to political stability and therefore to economic and financial stability. Second, since the 2011 revolution, the underlying economic situation in Tunisia has worsened. The economic and political uncertainties resulting from recent unrest and regime changes have led the major rating agencies to degrade Tunisian sovereign ratings in early 2011. However, banks were the first victims of the post-revolutionary period, as the Tunisian banking sector suffered an economic downturn involving "Crisis of liquidity, fall of investments, increase of doubtful debts, weak recovery 1 ..." Third, despite the return of bank shares four years after the revolution, the sector has not yet emerged from the crisis. Liquidity is still under pressure, competition is raging and becoming more aggressive and private investment has not yet resumed. At this stage, understanding the risk behavior of banks is essential from the point of view of financial stability.

At this stage, the contribution of our article to literature is twofold. On the one hand, to our knowledge, few studies have examined the cumulative impact of banking governance, particularly board characteristics and ownership structure, on the main banking risks of Tunisian banks. On the other hand, given that the Tunisian banking sector is exposed to certain disruptions related to various environmental, economic and political changes, risk management measures become a necessity to strengthen the role of banks in the economy and system restructuring. Hence, we provide bankers with tools to more effectively manage bank stability through the monitoring of credit and liquidity risks.

\footnotetext{
1 As a result of these events, the Central Bank of Tunisia (BCT) immediately launched a plea for tighter banking regulation, but the Tunisian banking system continues to suffer from structural problems and long-standing assets.
} 
The next section (2) will give a brief literature review. An overview of Tunisian Bank System intermediation is presented in section 3. Empirical methodology is explained in section 4. A discussion of the major findings is presented in section 5, while section 6 concludes.

\section{Corporate Governance and Bank Attitude towards Credit and Liquidity risk}

Literature review of the ownership structure and board characteristics are at the heart of this article, where our banking governance mechanisms are presented in two categories as follows:

\subsection{Characteristics of the board of directors}

\subsubsection{Board Size and Bank Risks}

The size of the board is an indicator of the number of board members. A very small board may have difficulty resisting management and dealing with the different risks of the banking sector. A very large board may also be unable to effectively oppose management. This suggests that board effectiveness in promoting shareholder interests may be related to board size in a nonlinear fashion. This measure has been used in previous work, such as Simpson and Gleason (1999), Sumner and Webb (2005) and Pathan (2009), where they examined the link between board size and bank risks. Since studies on the relationship between board size and bank risks have yielded contradictory results, we present two parts:

First, Jensen (1993) postulates that a reasonably sized board would be more effective because it allows for better coordination, faster decisions and reduced agency costs. Using a sample of 27 Egyptian banks covering the period 2006-2011, Abobakr and Elgiziry (2017) studied the influence of board characteristics on risk-taking by banks. Empirical results indicate that the size of the board has a significant positive effect on risk taking by banks. Adams and Mehran (2005) found that banks with larger boards are more exposed to bank risks. Manthos et al (2009) supported this finding when they explored the relationship between board size and liquidity risk for a sample of 127 banks from 10 countries for a period from 2000 to 2006. Their research showed that banks with large boards of directors invest more of their portfolios in risky activities and increase their liquidity risk. On the other hand, the work of Andres and Vallelado (2008) and Pathan (2009) have shown the contrary by demonstrating that a small number of directors on the board accelerate decision-making and facilitate control.

Second, Crespi et al. (2004), states that a large board of directors would be an organizational response to the company's environmental requirements by allowing the representation of different stakeholders. Faleye and Krishnan (2017) analyzed the effects of banking governance on risk taking. Empirical results indicate that banks with more efficient boards are less likely to lend to riskier borrowers. Faced with riskier borrowers, banks can practice credit rationing to avoid credit risk. Dannon P.H. (2009) studied the impact of a little board on the reduction of banking risks. He demonstrated the presence of a negative relationship between a small board of directors and banking risk, so that a large board of directors could better control the risk of investment projects through a diversified structure and better expertise. Based on the analysis of the literature we assume that a very small board may have difficulty resisting management, 
dealing with various risks for the banking sector, decision-making and control within banks. To better understand the impact of the size of the board on banking risks, we propose the following hypothesis:

\section{H1. A large size of the board increases bank credit and liquidity risks.}

\subsubsection{Duality and Bank Risks}

For Jensen (1993), the dual role of chairman of the board and chief executive officer is also likely to influence the level of risk-taking by the board of directors. This theory has been confirmed by the works of Dannon (2009). He noted that this dual has led to risky credit and investment decisions. Thus, in the case of duality, officer may have a higher authority than the board of directors, which leads to high exposure to different banking risks. In addition, Pathan S. (2009) examined the CEO's ability to control board-decision for 212 major US banks. Their main conclusions have shown that the duality of the two functions (CEO-Chairman) affects bank risk. This study of the Tunisian context reminds us of the note published in (2012) by the governor of the Central Bank ${ }^{2}$. Therefore, based on the rules of good governance of Tunisian companies, it is recommended to separate the two functions to ensure a good decision.

While some studies confirm that the combination of CEO functions has a positive impact on banking risk (Core et al. 1999, St Onge et al. 2001), others do not establish meaningful relationships (Conyon et al. Peck 1998, Cordeiro and Veliyath 2003). In our study, we believe that for the oversight function to be effective, it is recommended that the Director General not hold the position of Chair. On the basis of the literature review, we will establish the following hypothesis:

H2. The duality of the two functions of CEO and Chairman of the Board of Directors increases the risks of bank credit and liquidity.

\subsubsection{Board Independence and Bank risks}

The previous literature review has focused on the relationship between bank risk and the independence of the board of directors as a means of control to ensure greater effectiveness of risk management. An independent member of the board of directors is a board member free from any conflict of interest, independent in the protection of investors and the improvement of the quality of control exercised by the board. This person helps guide the bank's strategic policies and make them more effective in managing bank risks. Several studies have examined the effects of the presence of independent directors on the bank's board of directors. Agency theory suggests that independent directors play an important role in monitoring the performance of managers. Jensen (1993) and Pathan (2009) suggest that a significant percentage of "external" independent directors have a positive influence on the reduction of different banking risks. At this point, we distinguish two different flows:

\footnotetext{
${ }^{2}$ Such a note aims to establish a sound and prudent system and to ensure better management of banks.
} 
At first, Dahya et al. (2008) and Lin et al (2010) agree that the presence of independent directors on the board maximizes the wealth of shareholders and investors through their skills and experience in managing different risks. Francesco Vallascas et al. (2017) examined the impact of the board's independence on the risk taking of large banks following the global crisis of 2007-2009 for a sample of 262 large banks. Using ZScore and ROA as two measures of risk, their main results showed that greater independence of the board of directors led to more conservative risk taking in banking. This is due to the fact that the independent board favors the increase of banking capitalization and the risk reduction of banking portfolios after the global crisis. In response to this argument, Dionne and Triki (2004) stated that independent directors are not in a position to control director functions. Their strong presence on the board of directors has no impact on bank activities and does not cover risks. At this stage, we formulate the following hypothesis:

\section{H3. An independent board of directors reduces bank risk.}

\subsection{Ownership Structure}

\subsubsection{State Ownership and Bank Risk}

State administrators play a key role in managing credit risk and liquidity (Choi and Hasan 2005 and Gulamhussen and Guerreiro 2009). According to Konishi and Yasuda (2004), the presence of the state has a positive influence on bank credit risk. According to agency theory, stateowned banks would suffer less disciplinary effect from the financial market. This would encourage their leaders to follow their own interests, increase their profitability and reduce the level of risk for their institutions. On the other hand, for La Porta et al. (2002), state participation in commercial banks is a common fact and a clear consideration of their inefficiency as they are increasingly exposed to risks.

Some studies have focused on the governance of banks in emerging countries. These studies point out that for banks where the state or public institutions hold a significant portion of their capital, their results are positive, representing their efficiency and performance. Lang and So (2002) argue that banks characterized by the presence of the state are under increased pressure from their environment and more intense disciplinary effect from the financial market. As a result, state involvement in strategic economic sectors such as banks is needed to accelerate growth and performance. On the basis of the literature review, we formulate the following hypothesis:

H4. A high percentage of directors representing the state reduces the level of credit risk and increases liquidity risks.

\subsubsection{Foreign Director Ownership and Bank Risks}

The presence of foreign investors reinforces surveillance activities and encourages the bank's management to adopt more effective strategic and operational practices. In fact, banks with a high participation of foreign directors have better access to capital markets, greater ability to 
diversify risks and better opportunities to offer some of their services to foreign clients that are difficult to access at local banks. On the contrary, in the Tunisian context, for a sample of 8 Tunisian commercial banks, Chenini. H and Jarboui. A (2016) proved that a high percentage of foreign administrators reveal a negative impact on performance. Based on the review of the literature we formulate the following hypothesis:

H5. A high percentage of foreign directors negatively affect banking risks.

\subsubsection{Institutional Investor-Ownership and Bank Risks}

David H et al. (2012), used a sample of financial companies from 30 countries that were at the center of the economic crisis, to show that institutional ownership defined as "Percentage of shares held by institutional investors who have or represent $5 \%$ of Capital", experienced better stock returns during the crisis period and took more risks before the crisis, which resulted in greater shareholder losses over the same period. Vincent Aebi et al. (2012) studied whether risk management is linked to corporate governance mechanisms. The results show that the percentage of shares of a bank belonging to major shareholders holding 5\%or more, affects performance and banking risk. In the same context, Pathan, S. (2009) applied the ZScore technique to a sample of 212 large US financial firms for a period from 1997-2004. This technique showed that a lower percentage of institutional investors are positively associated with bank risk taking as banking associates.

H6. A high percentage of institutional investors holding 5\% or more of capital reduce banking risks.

\section{An Overview of the Tunisian Bank System}

The banking system has seen a reduction in available liquidity in recent years due to factors such as a large current account deficit of about 9\% of GDP in 2014. In order to remedy this problem and consolidate this segment, the authorities launched in 2014 an audit of the three main public institutions. In 2015, the three state-owned Tunisian banks "STB, BNA and BH" represented $38 \%$ of total assets. Their future seems vital for the system. In 2015, in order to carry out a radical restructuring for the benefit of the public banks reforms were introduced. The objective of such a restructuring is to make the latter more competitive and put them in a better position to finance the economy. Specifically, in July 2015, the government decided to restructure these three state-owned banks ${ }^{3}$. In Tunisia, bank loans to the economy in December 2016 amounted to 65.1 billion dinars data from the Central Bank of Tunisia. This rose from TND59.4 billion a year earlier, a 9.6\% increase. Bank loans from two years earlier had been TND56 billion, marking an increase of $16.3 \%$ over that period. Government bank credit had further increased to 8.5 billion dinars in November 2016, against 7.2 billion dinars at the end of 2015, with total loans equal to TND $6,818 \mathrm{~m}$ at the end of 2015 and TND7,286m at the end of 2016 .

\footnotetext{
${ }^{3}$ By recapitalizing STB and BH banks with respective amounts of TND756m and TND110m.
} 
Graph1 shows an average annual evolution in the two main banking risks over the period 19982015. These are credit risk (RCDR) and liquidity risk (LIQR). Credit risk (RCDR) has been almost stable over the period 1998-2015. This risk was approximately $52.11 \%$ in 1998 and reached $69.30 \%$ in 2015 . During this period, the level of credit risk was approximately $75 \%$. Regarding the liquidity risk of Tunisian banks, it can be interpreted in three phases. From 2000 to 2005 , the level of liquidity risk was around $100 \%$. This means that deposits were almost equal to the amount of credits. Tunisian banks have tried to cover the credits granted by the deposits collected. The second phase covers the period 2007-2009. During this period, the level of liquidity risk increased. This increase does not explain the increase in credits granted. On the contrary, this reflects the low level of deposits received by banks. The international financial crisis of 2008 was followed by a decline in the level of depositor confidence in banking institutions. For this reason, they preferred to withdraw and/or keep their capital outside banks. However, in the third phase, which covers the period 2010-2015, the descriptive statistics indicate a stable level of liquidity risk around $100 \%$. It can be considered that the credits granted $^{4}$ were covered by the deposits collected ${ }^{5}$.

Graph1. Average annual evolution of risk indicators for Tunisian banks during the period 19982015

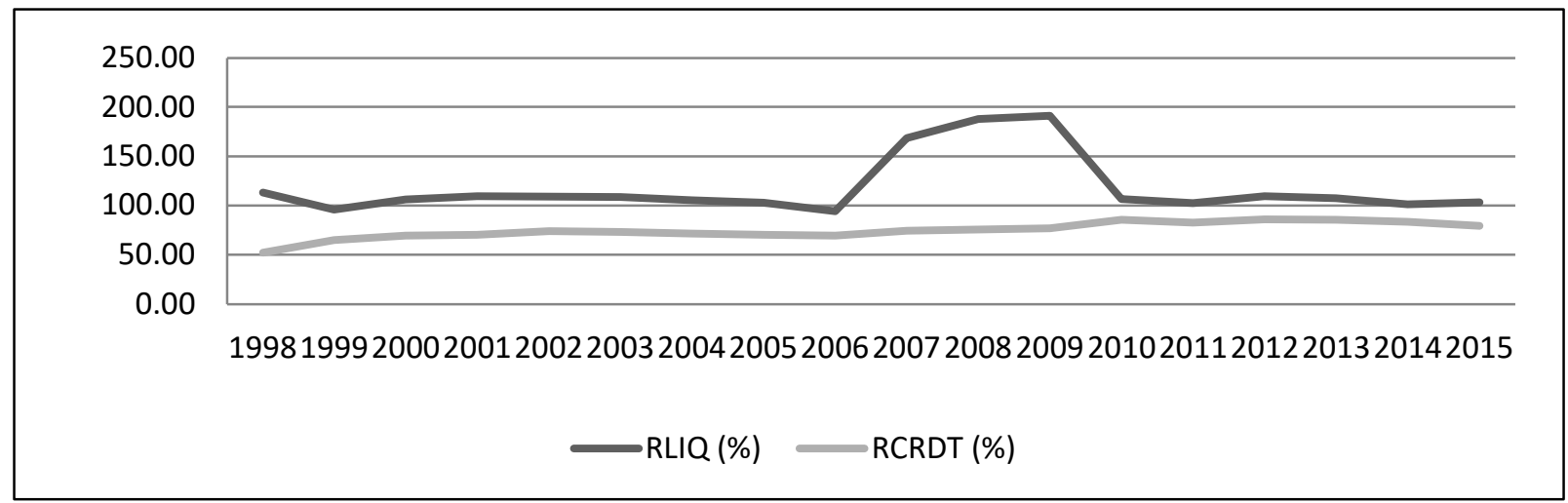

Source: Graph developed by the authors from the annual reports of banks.

\section{Empirical Analysis}

In this part of our study, we will begin by presenting the data and the methodology. Second, we will specify the econometric model used. The definition and measurement of variables are also provided in this step. Thirdly, we will interpret a possible econometric and economic association between banking governance and banking risks, namely liquidity risk and credit risk.

\footnotetext{
4 The total credits of the 10 banks in our sample changed from TND43, 412,765m in 2015 to TND40, 249,688m-in 2016. For more details see Appendix 1 "Evolution of deposits and credits of customers"

5 The total deposits of the 10 banks in our sample increased from TND42, 542,865m in 2015 to TND46, 367,969mMTD in 2016. For more details see Appendix1 "Evolution of deposits and credits of customers"
} 


\subsection{Data and Methodology}

An important step in our empirical study is to review the literature and identify the causalityrelated governance variables identified for credit risk and liquidity risk. To do this, we will analyze-two sets of data. The first set concerns components of banking governance mechanisms while the second set concerns the evolution of banking risks estimated by the control variables of our model. We will use a sample of 10 Tunisian banks covering the period 19982015.Although this Tunisian banking system covers more than 29 banks, we only consider these 10 banks for our study for several reasons. First, these banks are the best-tuned empirical studies for the Tunisian banking system. Therefore, we can ask for a comparison of the results. Second, these 10 banks are the most dynamic of the Tunisian economy. Thus, they monopolize the largest market share in terms of total assets (about 70\% of all assets), total loans, total deposits and $88 \%$ of total GDP. Third, we assume that governance mechanisms are different from other banks in terms of size, ownership, and banking strategies. The data for the governance variables are collected from the annual reports of the various banks, while the performance measures are collected from the financial statements of our sample.

\subsection{Model and Variable Definitions}

In this study, we will present a model to estimate the impact of internal banking governance mechanisms on the various risks to which banks are exposed. We have therefore developed a model that allows us to understand the complexity of the impacts of governance mechanisms and to avoid the problem of endogeneity between the governance variables and the credit and liquidity risk within each bank. Indeed, we have noted that large banks communicate more about their governance than smaller banks and often take proportionately more risks. For this reason, we will include the size of the bank as a control variable in our model. To empirically validate the association between governance risks and banking risks, two econometric models will be used in this study. The first will test relationship governance and credit risk while the second will examine the impact of governance mechanisms on liquidity. Recall that these models were inspired by previous studies with adjustments applicable to the Tunisian context. It should also be noted that following the unavailability of some data for the Tunisian case, the variables were replaced by others.

As an example, we cite the works of Cheneni and Jarboui (2016), Himaj.S (2014) and Aebi et al. (2012), Vallascas et al (2017) and Rose (2016). They are presented in the following form:

$\operatorname{RCDR}_{\mathrm{i}, \mathrm{t}}=\beta_{0}+\beta_{1}$ BDSIZE $_{\mathrm{i}, \mathrm{t}}+\beta_{2} \mathrm{DUAL}_{\mathrm{i}, \mathrm{t}}+\beta_{3}$ IND $_{\mathrm{i}, \mathrm{t}}+\beta_{4}$ STATE $_{\mathrm{i}, \mathrm{t}}+\beta_{5} \mathrm{EXT}_{\mathrm{i}, \mathrm{t}}+\beta_{6} \operatorname{INST}_{\mathrm{i}, \mathrm{t}}+\beta_{7}$
$\operatorname{CAP}_{\mathrm{i}, \mathrm{t}}+\beta_{8}$ SIZE $_{\mathrm{i}, \mathrm{t}}+\beta_{9} \operatorname{LIQR}_{\mathrm{i}, \mathrm{t}}+£_{\mathrm{i}, \mathrm{t}}$

LIQR $_{i, t}=\beta_{0}+\beta_{1}$ BDSIZE $_{i, t}+\beta_{2}$ DUAL $_{i, t}+\beta_{3}$ IND $_{i, t}+\beta_{4}$ STATE $_{i, t}+\beta_{5}$ EXT $_{i, t}+\beta_{6}$ INST $_{i, t}+\beta_{7}$ $\mathrm{CAP}_{\mathrm{i}, \mathrm{t}}+\beta_{8} \quad \mathrm{SIZE}_{\mathrm{i}, \mathrm{t}}+\beta_{9} \mathrm{RCDR}+£_{\mathrm{i}, \mathrm{t}}$

The definition and measurement of the variables used in both models are presented in the following Table: 
Table1. Definitions and Measures of Variables

\begin{tabular}{|c|c|c|c|}
\hline Variables & Definitions & Measurement & Sources \\
\hline \multicolumn{4}{|c|}{ Dependent Variables } \\
\hline RCDR & Credit risk & Total Loans/ Total Assets & $\begin{array}{l}\text { Iannotta et al. (2007), Chiorazzo et } \\
\text { al. (2008), and GhenmiA. et al. } \\
(2017)\end{array}$ \\
\hline LIQR & Liquidity risk & Total Loans /Total Deposit & $\begin{array}{l}\text { HakimiA. et al. (2017), } \\
\text { ZaghdoudiK. and HakimiA. (2017), } \\
\text { and GhenmiA. et al. (2017). }\end{array}$ \\
\hline \multicolumn{4}{|c|}{ Bank Specifics } \\
\hline SIZE & Bank size & Ln (total assets) & $\begin{array}{l}\text { Anginer et al. (2014), HakimiA. et } \\
\text { al. (2017) }\end{array}$ \\
\hline CAP & Capital & Total Equity/Total Assets & $\begin{array}{l}\text { Pathan (2009), HakimiA. et al. } \\
(2017)\end{array}$ \\
\hline \multicolumn{4}{|c|}{ Bank Governance Mechanisms } \\
\hline BDSIZE & Board Size & $\begin{array}{l}\text { Total number of directors on } \\
\text { the board. }\end{array}$ & $\begin{array}{l}\text { Switzer (2013) and Caspar Rose } \\
\text { (2016) }\end{array}$ \\
\hline DUAL & Duality & $\begin{array}{l}\text { Binary variable that takes } 1 \\
\text { when the executive director is } \\
\text { also chairman of the board } \\
\text { and } 0 \text { otherwise. }\end{array}$ & $\begin{array}{l}\text { Simpson and Gleason } \\
(1999), \quad \text { Pathan } \quad(2009) \text { and } \\
\text { CheniniH. and JarbouiA. (2016) }\end{array}$ \\
\hline IND & Board Independence & $\begin{array}{l}\text { Number of independent } \\
\text { directors / total number of } \\
\text { directors on the board. }\end{array}$ & $\begin{array}{l}\text { Pathan (2009) and CheniniH. and } \\
\text { JarbouiA. (2016) }\end{array}$ \\
\hline STATE & State Ownership & $\begin{array}{l}\text { Number of directors } \\
\text { representing the state / total } \\
\text { number of directors on the } \\
\text { board. }\end{array}$ & $\begin{array}{l}\text { Guerreiro (2009) and CheniniH. and } \\
\text { JarbouiA. (2016) }\end{array}$ \\
\hline EXT & $\begin{array}{ll}\text { Foreign } & \text { Director } \\
\text { Ownership } & \end{array}$ & $\begin{array}{l}\text { Number of foreign directors / } \\
\text { total number of directors on } \\
\text { the board. }\end{array}$ & $\begin{array}{l}\text { Choi and Hasan (2005), } \\
\text { Gulamhussen and GuerreiroL. } \\
\text { (2009) and CheniniH. and JarbouiA. } \\
\text { (2016) }\end{array}$ \\
\hline INST & $\begin{array}{l}\text { Institutional Investor } \\
\text { Ownership }\end{array}$ & $\begin{array}{l}\text { Percentage of investors } \\
\text { holding } 5 \% \text { or more of the } \\
\text { capital. }\end{array}$ & $\begin{array}{l}\text { Baysinger et al.(1991), Hugan et al. } \\
\text { (2011), and Aebi et al. (2012) }\end{array}$ \\
\hline
\end{tabular}

Source: Table made by authors based on the literature review.

\section{Results and Discussion}

Before interpreting the empirical results, we will give an overview of all the variables used in this study. The descriptive statistics presented in Table 2 give information on each variable, such 
as the mean value of the standard deviation and the maximum and minimum values. Table 2 below provides information on the average evolution, the dispersion with respect to the mean (standard deviation), the maximum and the minimum of each variable. This table provides readers with more information about our sample.

Table 2. Descriptive Statistics

\begin{tabular}{lccccc}
\hline Variable & OBS & Mean & Std. Dev. & Min & Max \\
\hline RCDR & 180 & 0.747 & 0.130 & 0.030 & 0.965 \\
LIQR & 180 & 1.179 & 0.366 & 0.551 & 2.597 \\
BDSIZE & 180 & 11.039 & 1.511 & 5.000 & 14.000 \\
DUAL & 180 & 0.594 & 0.492 & 0.000 & 1.000 \\
IND (Note 4) & 180 & 1.452 & 4.658 & 0.000 & 18.180 \\
STATE & 180 & 0.149 & 0.195 & 0.000 & 0.545 \\
EXT & 180 & 0.226 & 0.244 & 0.000 & 0.777 \\
INST & 180 & 0.369 & 0.204 & 0.000 & 0.875 \\
CAP & 180 & 0.089 & 0.031 & 0.011 & 0.175 \\
SIZE & 180 & 14.877 & 0.620 & 13.742 & 16.169 \\
\hline
\end{tabular}

Source: Author's calculations based on data from the banks' annual reports.

For dependent variables, the average value of credit risk is approximately $74.7 \%$, with a standard deviation of $13 \%$, a minimum value of $30 \%$ and a maximum value of $96.5 \%$. For the evolution of bank liquidity risk, the average is $117.9 \%$ with a standard deviation of $36.6 \%$, with maximum and minimum values of $55.1 \%$ and $25.97 \%$. This means that for liquidity risk, total credit is more than double the total deposit. However, we note that, with respect to liquidity risk, there is a significant gap between the maximum and minimum variables. This means that in our sample of Tunisian banks for the period 1998-2015, some are stable banks, and others are unstable. Most notable for this descriptive statistic is that the size of the bank for Tunisian banks is stable and uniform. There are no strong differences between mean, maximum and minimum values. Hence, we note that the average size of Tunisian banks in our sample is 14.877 in total assets, ranging from-13.742 to 16.169 . Unlike lending activity, which is considered in many studies as a proxy for credit risk, value is on average 0.089 . Regarding banking governance mechanisms, the size of the board of directors is on average 11.039. The minimum and maximum values are approximately 5 and 14 members respectively. For the presence of independent directors, the average value is about $1.452 \%$ with a maximum of $18.18 \%$. Such a value indicates that the presence of independent investors is low in Tunisian banks. This low rate indicates the importance of the dependent directors for the boards of directors of Tunisian banks. The duality is a binary variable, with classical values recorded as 0 for the minimum value and 1 as the maximum value. Regarding the presence of directors representing the state on the board, the value is an average of $14.9 \%$. The minimum value is equal to $0 \%$ with $54.4 \%$ as the maximum value. Similarly, for the percentage of foreign directors on the board, the average is $22.6 \%$ with $77.7 \%$ as the maximum. Finally, institutional investors on the board of directors average 36.9\%. Such an average indicates their strong presence on the board, which shows that institutional investors hold significant shares in bank 
capital.

After having an idea of the variables used in the econometric model, the correlation matrix is presented in the Table 3 below indicating the nature and level of correlation between the variables.

Table 3. Correlation Matrix of Banking Governance Variables

\begin{tabular}{|c|c|c|c|c|c|c|c|c|c|c|}
\hline & RCDR & Bdsize & Dual & Ind & State & Ext & Inst & Cap & Size & LIQR \\
\hline Rcdr & 1.0000 & & & & & & & & & \\
\hline Bdsize & -0.1756 & 1.0000 & & & & & & & & \\
\hline Dual & -0.1489 & -0.0838 & 1.0000 & & & & & & & \\
\hline Ind & 0.1682 & 0.1568 & -0.0913 & 1.0000 & & & & & & \\
\hline State & -0.1379 & 0.1888 & 0.3292 & 0.0850 & 1.0000 & & & & & \\
\hline Ext & 0.1228 & -0.2265 & -0.2890 & -0.1787 & -0.6254 & 1.0000 & & & & \\
\hline Inst & 0.1789 & -0.1353 & -0.4082 & -0.1147 & -0.6996 & 0.0801 & 1.0000 & & & \\
\hline Cap & 0.1149 & -0.1679 & -0.0309 & 0.0682 & -0.0885 & -0.1481 & -0.0621 & 1.0000 & & \\
\hline Size & 0.2565 & 0.1045 & -0.2815 & 0.1232 & -0.0086 & -0.0719 & 0.0385 & -0.2735 & 1.0000 & \\
\hline Liqr & 0.1288 & -0.0713 & 0.1329 & 0.1008 & 0.1312 & -0.0657 & -0.1057 & 0.2881 & -0.2242 & 1.0000 \\
\hline
\end{tabular}

Source: Author's calculations based on data from the banks' annual reports.

From Table 3 above, we can observe that there is no high correlation between the variables. It appears that the level of correlation between all the variables is very low. The highest correlation did not exceed a level of 33\%. It is registered between the two variables of STATE and DUAL. This low level of correlation confirms the absence of a multicollinearity problem in this study.

\subsection{Bank Governance and Credit Risk}

The results relating to the impact of governance mechanisms on bank credit risk are presented in Table4. Regarding the impact of governance variables on credit risk, it should be noted that these variable are introduced gradually for two reasons. The first one is to avoid multicolinearity problems between dummy variables. The second is to detect the partial impact of each variable of governance. 
Table 4. Estimation Results, Governance and Credit Risk (RCDR: Dependent Variable)

\begin{tabular}{|c|c|c|c|c|c|c|}
\hline & M1(RE) & M2 (RE) & M3 (RE) & M4 (RE) & M 5 (RE) & M 6 \\
\hline \multicolumn{7}{|l|}{ (RE) } \\
\hline RCDR & Coef, & Coef, & Coef, & Coef, & Coef, & Coef, \\
\hline \multirow[t]{2}{*}{ CAP } & 0.482 & 0.414 & 0.469 & 0.661 & 0.625 & 0.617 \\
\hline & 1.50 & 1.30 & 1.48 & $2.070^{* *}$ & $1.900^{*}$ & $1.920^{*}$ \\
\hline \multirow[t]{2}{*}{ SIZE } & 0.087 & 0.079 & 0.082 & 0.082 & 0.087 & 0.082 \\
\hline & $6.480^{* * *}$ & $5.670^{* * *}$ & $6.000^{* * *}$ & $6.090^{* * *}$ & $6.410^{* * *}$ & $5.800^{* * *}$ \\
\hline \multirow[t]{2}{*}{ LIQR } & 0.047 & 0.048 & 0.044 & 0.044 & 0.044 & 0.048 \\
\hline & $2.110^{* *}$ & $2.170^{* *}$ & $1.970^{* *}$ & $2.020^{* *}$ & $1.940^{*}$ & $2.040^{* *}$ \\
\hline \multirow[t]{2}{*}{ BDSIZE } & -0.005 & & & & & \\
\hline & -0.88 & & & & & \\
\hline \multirow[t]{2}{*}{ DUAL } & & -0.045 & & & & \\
\hline & & $-2.430 * *$ & & & & \\
\hline \multirow[t]{2}{*}{ IND } & & & 0.004 & & & \\
\hline & & & $2.160 * *$ & & & \\
\hline \multirow[t]{2}{*}{ STATE } & & & & -0.264 & & \\
\hline & & & & $-2.900 * * *$ & & \\
\hline \multirow[t]{2}{*}{ EXT } & & & & & 0.066 & \\
\hline & & & & & 1.44 & \\
\hline \multirow[t]{2}{*}{ INST } & & & & & & 0.085 \\
\hline & & & & & & 1.51 \\
\hline \multirow[t]{3}{*}{ _cons } & -0.594 & -0.489 & -0.57 & -0.539 & -0.676 & -0.611 \\
\hline & & & & & & - \\
\hline & $-2.610^{* * *}$ & $-2.200^{* *}$ & $-2.650^{* *}$ & $-2.530 * *$ & $-3.130^{* * *}$ & $2.760^{* * *}$ \\
\hline Hausman & 1.32 & 1.62 & 3.50 & 1.39 & 4.133 & 1.79 \\
\hline Prob chi2 & 0.857 & 0.804 & 0.477 & 0.847 & 0.459 & 0.795 \\
\hline Fisher & - & - & - & - & - & - \\
\hline Prob chi2 & - & - & - & - & - & - \\
\hline Wald & 45.84 & 52.43 & 50.27 & 55.38 & 44.81 & 40.17 \\
\hline Prob chi2 & 0.000 & 0.000 & 0.000 & 0.000 & 0.000 & 0.000 \\
\hline Obs & 180 & 180 & 180 & 180 & 180 & 180 \\
\hline
\end{tabular}

Source: Author's calculations based on data from the banks' annual reports.

The results show that the capital adequacy ratio increases credit risk. It is clear that a better capitalized bank remains more stable and profitable. In this study, a high capital ratio leads to an increase in credit risk. This result can be explained as follows. Highly capitalized banks may engage in speculative and risky behavior. A sufficiently capitalized bank seeks to reinvest this capital to be more profitable. The search for this profitability may encourage banks to sometimes be more flexible in terms of credit distribution. This flexibility is based on the distribution of loans without requiring sufficient guarantees or, in some cases, the financing of 
risky projects, generally with high rates of return, but with a low probability of success. The size of the bank is positively and significantly correlated with credit risk. The big banks are difficult to control and manage. As a result, credit decisions can be stifled. Big banks are constrained by a problem of asymmetric information as a result of their large number of customers. This can have a negative influence on decision-making and increases the credit risk. There is a second argument explaining this positive association between size and credit risk. In general, the big banks are heavily involved in financing well-defined industries such as tourism or agriculture. However, these sectors depend on economic and political stability (tourism) as well as climatic conditions (agriculture). Take the case of the three public banks in Tunisia that have heavily financed the tourism sector. After the Tunisian revolution of 2011, there was a fall in this sector because of the flight of tourists to other more stable and secure countries. Tourism companies were unable to meet their commitments and banks have been exposed to credit risk. As a result, our results are divergent from the work of Saunders et al. (1990), Chen et al. (1998), Cebenoyan et al. (1999) and Legginson (2005). When it comes to liquidity risk, it has a positive and significant correlation with credit risk. This association seems to also be reciprocal. In other words, an increase in credit risk leads to an increase in liquidity risk. A bank with liquidity deficits may be the result of capital losses and interest. Our results are consistent with those of Douglas et al. (2005), Gorton and Metrick (2010) and He and Xiong (2012).

In addition to traditional variables that may affect credit and liquidity risk, the banking literature has shown the importance of governance mechanisms. The main empirical results show that the sign of the coefficient attached to the duality variable is statistically significant and negative. In the banks in our sample, the more the duality increases, the lower the credit risk. We note that the combination of control and enforcement powers in Tunisian banks ensures better management of credit risk. Our results are consistent with the work of Malette et al. (1995) and Bebchuk and Fried (2006), where when the executive director combines both functions at the same time, he has more power to control board decisions to serve his own interests and those of shareholders. As a result, we can say that the duality of the two functions CEO and Chairman of the Board" reduces the level of credit risk. H2 is rejected.

In addition, we note that for our sample, the presence of independent directors on the board is weak, while increased independence can in theory improve management control and oversight. This can be explained by the fact that independent directors are less familiar with the bank with respect to the board of non-independent directors. Our results are contradictory to those of Caspar Rose (2016) who found that banks with more independent directors limited their exposure to risk. Our results were confirmed and followed by structural changes for Tunisian banks from the year 2016. These changes included the addition of independent directors to the boards of directors. They were extended to all banks under "article 47" of the new banking law6. At this stage, we conclude that the weak presence of independent directors in our Tunisian banks positively influences the level of credit risk. Therefore, H3 is rejected.

\footnotetext{
6 According to Law No. 2016-48 of 11 July 2016, relating to banks and financial institutions, "the board of directors or the supervisory board of a bank or financial institution must include at least two independent members of the shareholders and a member representing the smaller shareholders within the meaning of the laws and regulations relating to the financial market, as regards institutions listed on the Tunis Stock Exchange ".
} 


\section{Al Macrothink Institute ${ }^{\mathrm{TM}}$}

In the same context, we note that the percentage of directors representing the state significantly reduces the credit risk at the $1 \%$ level. In accordance with the work of Choi and Hasan (2005) and Gulamhussen and Guerreiro (2009), state administrators play a role of guarantor in the management of credit risk. They reduce the level of risk to which their institutions are exposed. In our study, according to the negative sign of the coefficient attached to the presence of directors representing the state, it can be concluded that state participation preserves the interests of Tunisian banks not only as shareholders, but also as regulators. Therefore, H4 is accepted.

\subsection{Bank Governance and Liquidity Risk}

Table5 presents the results of estimates of the impact of governance mechanisms on liquidity risk. Our governance variables are introduced gradually into the econometric model in order to detect the partial impact of each governance mechanism on the liquidity risk of banks.

Table5.Estimation Results: Governance and Liquidity Risk (Dependent Variable LIQR)

\begin{tabular}{|c|c|c|c|c|c|c|}
\hline & M1(RE) & M2 (RE) & M3 (RE) & M4 (RE) & M 5 (RE) & M 6 (RE) \\
\hline LIQR & Coef, & Coef, & Coef, & Coef, & Coef, & Coef, \\
\hline \multirow[t]{2}{*}{ CAP } & 2.933 & 2.682 & 2.619 & 2.688 & 4.084 & 3.938 \\
\hline & $3.020^{* * *}$ & $3.020 * * *$ & $2.840^{* * *}$ & $3.070 * * *$ & $3.660^{* * *}$ & $3.600 * * *$ \\
\hline \multirow[t]{2}{*}{ SIZE } & -0.129 & -0.102 & -0.13 & -0.122 & -0.132 & -0.151 \\
\hline & $-2.720 * * *$ & $-2.160^{* *}$ & $-2.810^{* * *}$ & $-2.740 * * *$ & $-2.600 * * *$ & $-2.980 * * *$ \\
\hline \multirow[t]{2}{*}{ RCDR } & 0.478 & 0.462 & 0.422 & 0.506 & 0.492 & 0.522 \\
\hline & $2.070^{* * *}$ & $2.210^{* *}$ & $1.930 * *$ & $2.440^{* *}$ & $1.900 *$ & $2.030^{* *}$ \\
\hline \multirow[t]{2}{*}{ BDSIZE } & -0.001 & & & & & \\
\hline & -0.040 & & & & & \\
\hline \multirow[t]{2}{*}{ DUAL } & & 0.086 & & & & \\
\hline & & 1.570 & & & & \\
\hline \multirow[t]{2}{*}{ IND } & & & 0.006 & & & \\
\hline & & & 1.130 & & & \\
\hline \multirow[t]{2}{*}{ STATE } & & & & 0.328 & & \\
\hline & & & & $2.480 * *$ & & \\
\hline \multirow[t]{2}{*}{ EXT } & & & & & 0.353 & \\
\hline & & & & & $2.100 * *$ & \\
\hline \multirow[t]{2}{*}{ INST } & & & & & & 0.574 \\
\hline & & & & & & $2.290 * *$ \\
\hline \multirow[t]{2}{*}{ _cons } & 2.486 & 2.056 & 2.556 & 2.332 & 2.327 & 2.467 \\
\hline & $3.460 * * *$ & $2.890 * * *$ & $3.740^{* * *}$ & $3.520^{* * *}$ & $3.220 * * *$ & $3.450^{* * *}$ \\
\hline Hausman & 2.01 & 7.83 & 5.35 & 4.76 & 16.32 & 15.99 \\
\hline Prob chi2 & 0.733 & 0.098 & 0.235 & 0.313 & 0.002 & 0.003 \\
\hline Fisher & - & - & - & - & 7.50 & 7.74 \\
\hline Prob chi2 & - & - & - & - & 0.000 & 0.000 \\
\hline Wald & 25.51 & 28.52 & 26.98 & 32.75 & - & - \\
\hline Prob chi2 & 0.000 & 0.000 & 0.000 & 0.000 & - & - \\
\hline Obs & 180 & 180 & 180 & 180 & 180 & 180 \\
\hline
\end{tabular}

Source: Author's calculations based on data from the banks' annual reports. 
Table5 presents the results of the estimates of the impact of governance mechanisms on liquidity risk. The capital adequacy ratio is positively correlated with liquidity risk. In other words, any increase in this ratio increases liquidity risk. This result seems surprising, as the most capitalized banks are less exposed to liquidity risk. Having sufficient capital is a very positive signal sent to the market about the solvency of the bank and its very low credit risk. This reduces the bank's risk of bankruptcy. A highly capitalized bank versus a weakly capitalized bank does not need to borrow to finance a certain level of assets. The use of its selffinanced capital to finance a project indicates to the market that the bank is very confident in its projects. These results are in contradiction with the work of Olivier J. (2010), Liu et al. (2010), Ben Naceur et al. (2010), GarcíaH. et al. (2009), and PasiourasF. and KosmidouK. (2007).The size of the bank has a negative and significant effect at the $1 \%$ level for liquidity risk. Any increase in size is associated with a reduction in liquidity risk. The larger the size, the more the bank must manage its risks. This size may result from an aggressive growth strategy, which does not necessarily lead to an improvement in the bank's performance. Smaller banks can better withstand difficult economic conditions. Our results are consistent with the work of Stiroh et al. (2006), Barros et al. (2007) and De.Jonghe (2010). When it comes to credit risk, it seems to have a positive and significant impact on liquidity risk. This result is expected given the reciprocal relationship between credit risk and liquidity risk. Credit risk often leads to a loss of capital and interest. An increase in this risk increases liquidity risk. Banks specializing in customer loans are more exposed to liquidity risk. When banks have a comparative advantage in providing credit to certain industries, financial integration may encourage banks to specialize in lending. Greater concentration of loans does not necessarily increase risk, as a well-functioning interbank market provides the necessary diversification. Our results corroborate the work of Doriana C. (2013) and Kim (2011). Finally, table5 shows that the presence of the state, the presence of institutional investors and the percentage of foreign directors significantly increase liquidity risk.

The percentage of institutional investors has a positive and significant impact on liquidity risk at the $5 \%$ level. In our sample we noted that the percentage of institutional investors is approximately $36.9 \%$. This can be confirmed by the work of Pathan S. (2009) who suggests that a lower percentage of institutional investors is positively associated with banking risk taking as banking associates. A second explanation can be presented, from where, based on agency theory, risk-taking behavior is influenced by conflicts between managers and shareholders. For their part, managers are reluctant to take risks to protect their position and personal benefits, while shareholders with a diversified portfolio are encouraged to increase bank risk. In this study, we conclude that the percentage of institutional investors can positively affects the liquidity risk of banks. As a result, H5 is rejected.

Regarding the impact of state ownership on bank risk taking in the case of liquidity risk, we find from table 5 the coefficient of the state variable is significantly positive for our model. Our results have been confirmed by the works of Srairi(2013), Berger and Udell(2005), Iannotta, Nocera and Sironi(2007).They found a positive and significant association between state participation in banking property and risk. This can be explained by the fact that state-owned banks have higher proportions of non-performing loans than other banks. We confirm that the 
presence of state participants on the board increases the risk of bank liquidity. At this stage, H4 is accepted.

From our results, it appears that the percentage of foreign directors positively affects the liquidity risk of Tunisian banks. The results indicate that there is a positive and statistically significant relationship between foreign participation and bank liquidity. In the Tunisian context, this supports the idea that foreign directors do not know the economic nature of the country. They also bring new perspectives to the local banking business, thus reducing their dependence on traditional sectors of activity as they seek other sources of activity that are riskier. In our study, we conclude that the percentage of foreign directors positively affects the liquidity risk of banks. In the context of our study, this can be explained by the fact that foreign administrators are generally unaware of the Tunisian economic reality and may have difficulties in implementing and applying their governance concepts to the specific case of Tunisian commercial banks. Thus, H6 is rejected.

\section{Conclusion and Policy Recommendations}

Given the crucial role played by banks in a developing country like Tunisia, it is important to maintain their stability. Based on our experience in this area, we have provided a model to study the impact of board and shareholding structure characteristics on bank risk from a sample of 10 Tunisians banks covering the period (1998-2015). We first analyzed the impact of banking governance on credit risk. Our main econometric results have shown that duality and state ownership reduce credit risk, while the ownership of independent directors is associated with an increase in credit risk. In a second step, by analyzing the impact of governance mechanisms on liquidity risk, we found that the ownership of institutional investors, state ownership and the ownership of foreign directors positively impacted liquidity risk of banks.

From our results, it appears that Tunisian banks are not required to seek banking stability unless specific laws or regulations require it. Interestingly, such targets, banks can lead to risks leading to financial contagion. In this context, a legal change should be evaluated. For example, the board should be equipped with new skills. We have been informed that these directors have accumulated successful experience in the banking system which should help to consolidate the banking stability. In addition, Tunisian banks are invited to reduce the presence of foreign investors as a result of their positive impact on risks. Similarly, the authorities are urged to radically restructure Tunisian banks to make them competitive and put them in a better position to finance the economy. According to our results, it is recommended to improve the measurement methodology of corporate governance, as most banks do not communicate indicators on their governance practices. As a result, financial regulators should focus on banks with weaker corporate governance and evaluate policy measures to improve them. By doing this, banks would be healthier and more sustainable over time.These results could be of great importance to decision makers. However, banks and national authorities need more work to establish effective risk governance frameworks. On the one hand, banks need to strengthen their supervisory powers. The results of our study have certain limitations. First, we have selected the 10 most dynamic banks and those most involved in the financing of the economy. 
Our sample seems too limited for generalization. Second, we limited ourselves to the use of internal governance variables without introducing external governance mechanisms. However, as a first step, we will introduce new internal governance variables that appear to have an effect on bank risks. In a second step, we will focus on future research on the effect of internal and external governance mechanisms at the same time.

\section{List of abbreviations}

CBT: Central Bank of Tunisia.

CEO: Chief Executive Officer.

FSB: Financial Stability Board.

MENA: Middle East and North Africa.

NBI: Net Banking Income.

TSE: Tunis Stock Exchange.

\section{References}

Abobakr M., \& Elgiziry K. (2017). The Relationship between Board of Directors' Characteristics and Bank Risk-Taking: Evidence from Egyptian Banking Sector. Journal of Finance and Accounting, 5(1), 24-33. https://doi.org/10.11648/j.jfa.20170501.13.

Aebi V., Sabato G., \& Markus. (2012). Risk management, corporate governance, and bank performance in the financial crisis. Journal of Banking \& Finance, 36(2012), 3213-3226. https://doi.org/10.1016/j.jbankfin.2011.10.020.

Andres P., \& Vallelado E. (2008). Corporate governance in banking: The role of the board of directors. Journal of Banking and Finance, 32, 2570-2580. https://doi.org/10.1016/j.jbankfin.2008.05.008.

Anginer D., Demirguc-Kunt, \& Zhu M. (2014). How does competition affect bank systemic risk? Journal of Financial Intermediation, 23(1), 1-26. https://doi.org/10.1016/j.jfi.2013.11.001.

Baysinger B.D., \& Zardkoohi. (1986). Technology, Residual Claimants, and Corporate Control. Journal of Law, Economics, and Organization, 2(2), 339-349.

Bebchuk L.A., \& Fried J. M. (2006). Pay without Performance: Overview of the Issues. Academy of Management Perspectives, 20, 5-24. .https://doi.org/10.5465/amp.2006.19873407.

Ben Naceur S., \& Goaied M. (2008). The Determinants of Commercial Bank Interest Margin and Profitability: Evidence from Tunisia. Frontiers in Finance and Economics, 5(1), 106-130.

Berger A.N., Miller N.H., Petersen M.A., Rajan R.G., \&Stein J.C. (2005). Does function follow organizational form? Evidence from the lending practices of large and small banks. Journal of 
Financial Economics, 76,237-269. https://doi.org/10.1016/j.jfineco.2004.06.003.

Blanchard D., \& Dionne G. (2003). Risk Management and Corporate Governance. Working Paper, pp. 3-4.

Bonfim D. (2009). Credit risk drivers: Evaluating the contribution of firm level information and of macroeconomic dynamics. Journal of Banking \& Finance, 33, 281-299. https://doi.org/10.1016/j.jbankfin.2008.08.006.

CasparR. (2016). Firm performance and comply or explain disclosure in corporate governance. European Management Journal, 34(2016), 202-222.

Cebenoyan A. Sinan Cooperman and Register C. (1999). Ownership structure, Charter Value, and Risk-Taking Behavior for Thrifts. Financial Management, 28(Spring), 4360.https://doi.org/10.2307/3666116.

Chenini H., \& Jarboui A. (2016). Analysis of the Impact of Governance on Bank Performance: Case of Commercial Tunisian Banks. Journal of the Knowledge Economy, pp 1-25.

Chen W. P, Chung H., Hsu T. L., \&Wu T. L. (2010). External Financing Needs, Corporate Governance and Firm Value, Corporate Governance: An International Review, 18(3), 234-249.

Chiorazzo V. Milani C., \& Salvini F. (2008). Income diversification and bank performance: evidence from Italian banks. Journal of Financial Services Research, 33,181203.https://doi.org/10.1007/s10693-008-0029-4.

Choi S., \& Hasan I. (2005). Ownership, Governance, and Bank Performance. Financial markets, institutions and instruments, 14(4), November.

Conyon M. J., \& Peck S. I. (1998). Board control, remuneration committees, and top management compensation. Academy of Management Journal, 41(2), 146-157. https://doi.org/10.5465/257099.

Core John E., \& Guay W. R. (1999). The use of equity grants to manage optimal equity incentive levels. Journal of Accounting \& Economics, 28(2), 151-184. https://doi.org/10.1016/S0165-4101(99)00019-1.

Dahya, L.G. Garcia, \& BommelJ.V.(2008). One man two hats: What's all the commotion! The Financial Review, 44(2), (2009), 179-212. https://doi.org/10.1111/j.1540-6288.2009.00215.x.

Dannon P.H. (2009). Mécanismes Internes de Gouvernance Bancaire et Risques Financiers dans la Zone UEMOA: une analyse économétrique par les données de panel.

David H. Erkens Pedro. (2012). Matos Corporate governance in the 2007-2008 financial crisis: Evidence from financial institutions worldwide. Journal of Corporate Finance, 18, 389-411. https://doi.org/10.1016/j.jcorpfin.2012.01.005.

De Jonghe. (2010). Back to the basics in banking? A micro-analysis of banking system stability. Journal of Financial Intermediation, 19, 387-417.https://doi.org/10.1016/j.jfi.2009.04.001.

Delis M. D., Gaganis C., \& Pasiouras F. (2009). Bank liquidity and the board of directors. 
MPRA Paper No. 1887.

Diamond D.W., \& Rajan R. (2005). Liquidity Shortages and Banking Crises. Journal of Finance, American Finance Association, 60(2), 615-647, 04.

DionneG., \& Triki. (2004). On Risk Management Determinants: What Really Matters?. European Journal of Finance, 19(2).

Dionne, G. (2013). Gestion des risques : historique, définition et critique.Mars, 81(1-2).

Dittmar A., J. Mahrt-Smith J., \& Servaes H. (2007). International corporate governance and corporate cash holdings. Journal of Financial and Quantitative Analysis, 38, 111-133.

Djebali N., \& Zaghdoudi K. (2017). Bank Governance, Risk and Bank Insolvency: Evidence from Tunisian Banks. International Journal of Accounting and Financial Reporting, 7(2). https://doi.org/10.5296/ijafr.v7i2.12218.

Doriana C. (2013). Determinants of Bank Liquidity Risk within the Context of Euro Area. Interdisciplinary Journal of Research in Business, 2(10), 51- 64)

Faleye O., \& Krishnan K. (2017). Risky Lending: Does Bank Corporate Governance Matter? Journal of Banking and Finance. https://doi.org/10.1016/j.jbankfin.2017.06.011.

Fernandes N., \& Fich, E. (2009). Does Financial Experience Help Banks during Credit Crises?. Unpublished Working Paper, IMD-Lausanne, Switzerland.

García-Herrero A., GavilaS., \&Santaba'rbaraD. (2009). What explains the low profitability of Chinese banks?. Journal of Banking and Finance, 33, 2080-2092. https://doi.org/10.1016/j.jbankfin.2009.05.005.

Gorton and Metrick (2012). Securitized banking and the run on repo. Journal of Financial Economics, 104, 425-451. https://doi.org/10.1016/j.jfineco.2011.03.016.

Gorton,G., \& MetrickA. (2010). Regulating the Shadow Banking System. forthcoming in the Brookings Papers on Economic Activity.

Gulamhussen M.A., \& GuerreiroL. (2009). The influence of foreign equity and board membership on corporate strategy and internal cost management in Portuguese banks. Management Accounting Research, 20, 6-17. https://doi.org/10.1016/j.mar.2008.10.006.

HakimiA., Zaghdoudi. K., Zaghdoudi T., \& Djebali N. (2017). What threatens Tunisian banking stability? Bayesian Model versus Panel data analysis. International Journal of Business and Finance Research, 11(2), 21-37.

He W., \& Xiong. (2012). Rollover risk and credit risk. Journal of Finance, 67,391-429. https://doi.org/10.1111/j.1540-6261.2012.01721.X.

He.W., \& Xiong. (2012). Dynamic debt runs. Review of Financial Studies, 25, 799-1843. https://doi.org/10.1093/rfs/hhs004.

Iannotta G.,Nocera G., \&Sironi A. (2007). Ownership Structure, Risk and Performance in the 
European Banking Industry. Journal of Banking and Finance,31,21272149.https://doi.org/10.1016/j.jbankfin.2006.07.013.

Jensen, M.C. (1993). The Modern Industrial Revolution, Exit and the Failure of Internal Control Systems. Journal of Finance, 48, 831-880.https://doi.org/10.1111/j.15406261.1993.tb04022.x.

Jonghe O. D.(2010). Back to the basics in banking? A micro-analysis of banking system stability. Journal of Financial Intermediation, 19(3), 387-417. https://doi.org/10.1016/j.jfi.2009.04.001.

Kashyap. A Rajan R., \& Stein J. (2008). Rethinking Capital Regulation. Working paper, University of Chicago and Harvard University.

Kimball R. C. (1997). Specialization, risk, and capital in banking. New England Economic Review.

Konishi, \& Yasuda. (2004). Factors affecting bank risk taking: Evidence from Japan. Journal of Banking \& Finance, 28(1), 215-232.

La Porta R., Lopez-de-Salines F., \& Shleifer A. (2002). Government ownership of banks. Journal of Finance, 57(1), 265-301. https://doi.org/10.1111/1540-6261.00422.

Lin et al. (2010). Audit Quality, Corporate Governance, and Earnings Management: A MetaAnalysis. International Journal of Auditing, 14(1), 57 - 77.

Lipton, M., \& Lorsch, J. W. (1992). A modest proposal for improved corporate governance.Business Lawyer, 48, 59- 77.

Mamoghli C., \& Dhouibi R. (2009). Bank Corporate Governance and Insolvency Risk Evidence from an Emerging Market. Working paper, 32 p.

Pasiouras,F., \& Kosmidou, K. (2007). Factors influencing the profitability of domestic and foreign commercial banks in the European Union. International Business and Finance, 21, 222-237. https://doi.org/10.1016/j.ribaf.2006.03.007.

Pathan, S. (2009). Strong boards, CEO power and bank risk-taking. Journal of Banking and Finance, 33, 1340-1350. https://doi.org/10.1016/j.jbankfin.2009.02.001.

Saunders, A.,Strock E., \& Travlos N. (1990). Ownership structure, deregulation and bank risk taking. Journal of Finance 45, 643-654. https://doi.org/10.1111/j.1540-6261.1990.tb03709.x.

Shkendije H. (2014). Corporate Governance in Banks and its Impact on Risk and Performance: Review of Literature on the Selected Governance Mechanisms. Journal of Central Banking Theory and Practice, Central bank of Montenegro, 3(3), 53-85.

SrairiS. (2013). Ownership structure and risk-taking behaviour in conventional and Islamic banks: Evidence for MENA countries. Borsa Istanbul Review, 13(4).

Stiroh, K., \&Rumble A. (2006). The dark side of diversifcation: The case of US financial holding companies. Journal of Banking and Finance, 30(8), 2131-2161 
https://doi.org/10.1016/j.jbankfin.2005.04.030.

Sumner S., \& Webb E. (2005). Does corporate governance determine bank loan portfolio choice?. Journal of Academy of Business and Economics.

Switzer L. (2012). The Relative Performance of Small Cap Firms and Default Risk across the Business Cycle: International Evidence. International Journal of Business, 17(4).

Switzer L. (2013). Default Risk Estimation, Bank Credit Risk, and Corporate Governance. Financial Markets, Institutions \& Instruments, 22(2), 91-112.

Taylor, J.B. (2009). The financial crisis and the policy responses: an empirical analysis of what went wrong. National Bureau of Economic Research Working Paper, 14631.

Webb,D. C. (1992). Two-Period Financial Contracts with Private Information and Costly, State Verification. The Quarterly Journal of Economics, 107,1113-1123. https://doi.org/10.2307/2118378.

ZaghdoudiK., \& Hakimi A. (2017). Liquidity risk and bank performance: An empirical test for Tunisian Banks. Business Economic Research, 7(1), 46-57.

ZaghdoudiK. and HakimiA. (2017). The determinants of liquidity risk: Evidence from Tunisian Banks. Journal of Applied Finance and Banking, 7(2,5), 71-81.

\section{Appendix}

Appendix1. Evolution of Deposits and Credit of Tunisian Banks per mTDN

\begin{tabular}{|c|c|c|c|c|c|c|c|c|}
\hline \multirow[b]{2}{*}{ Rang } & \multirow[b]{2}{*}{ Denomination } & \multirow[b]{2}{*}{ Abbreviation } & \multicolumn{3}{|c|}{ Deposits Evolution } & \multicolumn{3}{|c|}{ Credits Evolution } \\
\hline & & & 2016 & 2015 & Var & 2016 & 2015 & Var \\
\hline 1 & AMEN Bank & $\mathrm{AB}$ & $5,116,107$ & $5,142,391$ & $-0.5 \%$ & $5,890,736$ & $5,971,463$ & $-1.4 \%$ \\
\hline 2 & Arab Tunisian Bank & ATB & $4,082,786$ & $3,876,934$ & $5.3 \%$ & $3,665,425$ & $3,331,679$ & $10.0 \%$ \\
\hline 3 & Attijari Bank & ATTIJARI & $5,460,301$ & $4,870,850$ & $12.1 \%$ & $4,482,854$ & $3,836,075$ & $16.9 \%$ \\
\hline 4 & International Arab Bank of Tunisia & BIAT & $9,078,141$ & $8,092,342$ & $12.2 \%$ & $7,679,218$ & $6,583,294$ & $16.6 \%$ \\
\hline 5 & Bank of Tunisia & BT & $3,153,153$ & $2,847,254$ & $10.7 \%$ & $3,655,442$ & $3,412,300$ & $7.1 \%$ \\
\hline 6 & Banking Union for Trade and Industry & UBCI & $2,248,441$ & $1,958,564$ & $14.8 \%$ & $2,561,769$ & $2,381,519$ & $7.6 \%$ \\
\hline 7 & International Union of Banks & UIB & $3,661,507$ & $3,402,263$ & $7.6 \%$ & $4,126,831$ & $3,725,437$ & $10.8 \%$ \\
\hline 8 & Housing Bank & $\mathrm{BH}$ & $5,260,709$ & $4,696,798$ & $12.0 \%$ & $6,264,672$ & $5,342,413$ & $17.3 \%$ \\
\hline 9 & National Agricultural Bank & BNA & $6,946,257$ & $6,247,322$ & $11.2 \%$ & $7,286,380$ & $6,818,824$ & $6.9 \%$ \\
\hline 10 & Tunisian Bank Company & STB & 5443,353 & $5,285,081$ & $3.0 \%$ & $5,588,166$ & $5,341,440$ & $4.6 \%$ \\
\hline \multicolumn{3}{|c|}{ TOTAL } & $46,367,969$ & $42,542,865$ & $8.6 \%$ & $40,249,688$ & $43,412,765$ & $9.6 \%$ \\
\hline
\end{tabular}

Source: Data extracted from the ranking of Tunisian banks for the year 2014 and 2015 by the TSE. 